\title{
ZDROJ HODNÔT V KULTÚRNOM ŽIVOTE SLOVANOV'
}

\author{
A Source of Values in the Cultural Life of the Slavs
}

\author{
Ján Zozul'ak
}

DOI: 10.17846/CL.2019.12.1.13-21

\begin{abstract}
ZOZULAK, Ján. A Source of Values in the Cultural Life of the Slavs. Slavic script and Slavonic literature belong to the most important cultural values brought by ConstantineCyril and Methodius to Great Moravia. The source of these values was the Eastern Roman (Byzantine) Empire and its culture which significantly influenced the history of Slavic nations and their position within the European cultural space. The study discusses three historical documents which demonstrate the supremacy of the Byzantine Empire as a cultural centre viewed from the Slavs' perspective and clarifies the process of reception of Byzantine cultural and spiritual values in Slavic countries. Although the Cyrillo-Methodian mission requested by Rastislav, the Duke of Great Moravia, failed to include Great Moravia permanently into the countries belonging to the Byzantine sphere of influence, the creation of the Slavic alphabet, the origins of Slavonic literature and the use of a Slavic language in liturgy were the most efficient means to promote Byzantine influence on Slavic nations. Cultural legacy of the Cyrillo-Methodian mission moved to the South and Eastern Slavs who accepted Christianity of the Byzantine tradition and became the members of a large

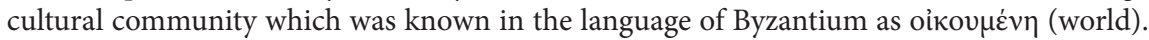
Many cultural elements which formed their value system became a part of their religious and everyday life.
\end{abstract}

Keywords: Constantine-Cyril, Methodius, Great Moravia, Byzantine Empire, culture, values, Slavic script, Slavonic literature

Abstrakt: ZOZULAK, Ján. Zdroj hodnôt v kultúrnom živote Slovanov. Slovanské písmo a slovanské písomníctvo patria $\mathrm{k}$ najdôležitejším kultúrnym hodnotám, ktoré na Velkú Moravu priniesli Konštantín Filozof (Cyril) a Metod. Zdrojom týchto hodnôt bola Východorímska (Byzantská) ríša, ktorá významne ovplyvnila smerovanie slovanských národov a ich postavenie $\mathrm{v}$ európskom kultúrnom priestore. Na základe troch historických textov poukážeme na uznanie prevahy Byzancie ako kultúrneho centra zo strany Slovanov a vysvetlíme proces recepcie byzantských kultúrnych a duchovných hodnôt v slovanských krajinách. Napriek tomu, že cyrilo-metodská misia vyžiadaná kniežatom Rastislavom nedokázala trvalo začlenit Velkú Moravu do okruhu krajín patriacich do sféry byzantského mocenského vplyvu, zostavenie slovanskej abecedy, vytvorenie slovanského písomníctva a zavedenie slovanského jazyka do liturgie vytvorilo najúčinnejší prostriedok na presadzovanie byzantského vplyvu medzi slovanskými národmi. Kultúrny odkaz cyrilo-metodskej misie prevzali južní a východní Slovania, ktorí sa začlenili do krestanstva byzantskej tradície a stali sa členmi velké-

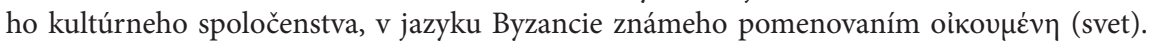
Do ich cirkevného a každodenného života sa v nezmenenej forme začali prenášat mnohé kultúrne prvky, ktoré formovali ich hodnotový systém.

Táto práca bola podporovaná Agentúrou na podporu výskumu a vývoja na základe Zmluvy č. APVV-160116 a vznikla tiež v rámci projektu KEGA č. 004UKF-4/2018 Európsky stredovek interaktívne. 
Klúčové slová: Konštantín-Cyril, Metod, Velká Morava, Byzantská ríša, kultúra, hodnoty, slovanské písmo, slovanské písomníctvo

\section{Úvod}

Východorímska (Byzantská) ríša významne ovplyvnila smerovanie slovanských národov a ich postavenie $\mathrm{v}$ európskom kultúrnom priestore. $\mathrm{V}$ tejto štúdii sa zamyslíme nad diachronickou hodnotou slovanského písma, ktoré umožnilo vytvorenie a rozvíjanie slovanského písomníctva. Slovanské písmo a slovanské písomníctvo patria k najdôležitejším kultúrnym hodnotám, ktoré na Vel'kú Moravu priniesli Konštantín Filozof (Cyril) a Metod. Napriek tomu, že vo vedeckých kruhoch sa vo všeobecnej rovine poukazuje na kultúrny odkaz cyrilo-metodskej misie, nie je dostatočne prebádaný rozsah a dôležitost' byzantských kultúrnych hodnôt, prenášaných do kultúrneho prostredia Slovanov. Tieto hodnoty významným spôsobom ovplyvňovali smerovanie predovšetkým južných a východných Slovanov, ktorí sa začlenili do krestanstva byzantskej tradície a stali sa členmi vel'kého kultúrneho spoločenstva. História však ukázala, že prenášanie kultúrnych hodnôt z Byzancie do slovanského prostredia vôbec nebolo jednoduchým procesom.

\section{Kultúrna prevaha Byzancie}

Uznanie prevahy Byzancie ako kultúrneho centra A. Tachiaos $(2006,24)$ odvodzuje z troch historických textov, na základe ktorých je presvedčený, že na jednej strane svedčia o nepopieratelnom diachronickom uznaní dominantnej hodnoty Byzancie zo strany Slovanov ako zdroja duchovného bohatstva, hodnôt a právnych noriem, ktoré sa v slovanskom prostredí budú rozvíjat' v nasledujúcich storočiach, a na druhej strane vymedzujú východiskový bod, z ktorého by malo začat nazeranie na proces recepcie byzantských kultúrnych a duchovných hodnôt v slovanských krajinách.

Prvým textom je 6. kapitola Života sv. Konštantína-Cyrila, v ktorom je zachytená Konštantínova diskusia s Arabmi v roku 851. Táto diskusia opisuje Konštantínov rozhovor so zástupcami intelektuálov arabského sveta v meste Sámarrá v Bagdadskom kalifáte, s ktorými diskutoval o témach náboženskej viery a vedeckých poznatkov. Na otázky, ktoré mu kládli arabskí mudrci, Konštantín pohotovo odpovedal, a oni sa ho prekvapení opýtali: „Ako to všstko vieš?“ (Život sv. Konštantína-Cyrila, kap. VI). Konštantín im presvedčivo odpovedal: „Ved’u nás vznikli všetky vedy. "(Život sv. Konštantína-Cyrila, kap. VI). J. Vašica $(1966,216)$ k tomu podáva takéto vysvetlenie: „Neskorši kalifovia sa zriekli puritánskej prostoty prvých Mohamedových nástupcov a vo svojich rozprávkovo krásnych sídlach pestovali umenie a vedu podla gréckeho spôsobu, učili sa gréckej filozofi, matematike, prírodným vedám a medicíne, gréckymi vzormi sa riadili aj v stavitelstve, vojenstve a námorníctve. Gréci si boli vedomí svojej kultúrnej prevahy a ich zmýšlanie dobre vystihujú uvedené Konštantínove slová."

Druhým textom je list vel'komoravského kniežata Rastislava byzantskému cisárovi Michalovi III. z roku 862, ktorý prostredníctvom svojich vyslancov poslal do Konštantínopola: „Náš lud zavrhol pohanstvo a dodržiava krestanské zákony, ale nemáme takého učitela, ktorý by nám naším jazykom vysvetlil pravú krestanskú vieru. Pošli nám teda, pane, takého biskupa a učitela, aby nás napodobnili aj iné krajiny, ked’ to uvidia. Lebo od vás sa do všetkých krajín šíri dobrý zákon." (Život sv. Konštantína-Cyrila, kap. XIV). ${ }^{2}$ Cisár Michal III. zareagoval na Rastislavovu

2 „Ljudem našim pohaňstva sja otvrhšim i po christanesk sja zakon držaščim, učitelja ne imam takovaho, iže by ny v svoj jazyk istuju viru christiaňskuju skazal, da byša i iny strany toho zrjašče podobilisja 
žiadost' a poslal mu list, v ktorom napísal: „Nuž prijmi dar väčší a vzácnejší ako všetko zlato a striebro i drahé kamene a pominutelné bohatstvo" (Život sv. Konštantína-Cyrila, kap. XIV). Týmito slovami deklaroval diachronickú hodnotu slovanského písma, ktoré sa bude rozvíjat v dalšom období. Cisár vo svojom liste dalej uvádza: „Boh, ktorý si želá, aby každý prišiel k poznaniu pravdy a snažil sa o vyšši stupeň dokonalosti, videl tvoju vieru a snahu, preto zjavil písmo pre váš národ. Tým urobil..., aby ste aj vy boli pripočítaní k vel'kým národom, ktoré oslavujú Boha svojím jazykom. A poslali sme ti toho, ktorému ho Boh zjavil, muža ctihodného a zbožného, velmi učeného a filozofa" (Život sv. Konštantína-Cyrila, kap. XIV). Slovanské písmo, takzvanú hlaholiku, vynašiel Konštantín, ako je zrejmé z d’alšieho textu Života sv. Konštantína-Cyrila: „Šiel teda filozof, a ako bolo jeho dávnym zvykom, oddal sa modlitbe spolu s d’alšími pomocníkmi. Čoskoro mu [ho] potom zjavil Boh, ktorý počuje modlitby svojich služobníkov, a ihned’zložil písmená a začal písat' slová Evanjelia: Na počiatku bolo Slovo a Slovo bolo k Bohu a Boh bol Slovo, ${ }^{3}$ a tak d'alej“ (Život sv. Konštantína-Cyrila, kap. XIV).

Tretím textom je list moskovského panovníka Symeóna byzantskému cisárovi Jánovi Kantakuzenovi z roku 1347, ktorý uznal, že „královstvo Rimanov, ale aj najsvätejšia velká Božia Cirkev ... je prameňom všetkej zbožnosti, učitelom zákonodarstva a posväcovania“4 (Miklosich Müller 1862, 263; Tachiaos 2006, 24).

\section{Byzantsko-slovanské vztahy}

Predtým, než pristúpime k analýze teoretických východísk absorbovania byzantských kultúrnych hodnôt v slovanských krajinách, stručne načrtneme kontakty medzi Byzanciou a Slovanmi, ktoré je možné sledovat' už v 7. storočí, ked’ sa slovanské kmene začali objavovat’ v blízkosti hraníc Byzantskej ríše. Trvalé usadenie sa Slovanov južne od Dunaja, ktorý bol zároveň severnou hranicou Byzantskej ríše, jej spôsobovalo vážne problémy, pretože odrážanie ich útokov sa stávalo čoraz tažšie. Táto realita viedla byzantských cisárov k systematickejšiemu zaoberaniu sa budúcnostou vztahov s nevítanými nájazdníkmi.

Pre Slovanov, usadených pri Dunaji, stále platila zásada, že oblasti, ktoré obsadili, mohli byt’ potenciálne znovu dobytými byzantskými územiami, ako je zrejmé zo slov cisára Romana v liste bulharskému panovníkovi Symeónovi (Tachiaos 1990, 15-19). Tento postoj Byzantíncov napriek tomu, že boli naklonení christianizácii Slovanov, vylučoval vytvorenie špeciálnej abecedy a písomného slovanského prejavu, ako konštatuje A. Tachiaos (2006, 24). K vytvoreniu slovanskej abecedy pristúpila Byzancia až vtedy, ked’vel'komoravské knieža Rastislav požiadal o učitela, ktorý by jeho lud vyučoval krestanskej viere $\mathrm{v}$ jazyku, ktorému by lud rozumel. $\mathrm{V}$ tejto súvislosti je dôležité si uvedomit, že Vel'ká Morava bola slovanským štátnym útvarom, ktorý nebol vytvorený na dobytých byzantských územiach, preto pre Byzantskú ríšu nepredstavovala bezprostredné nebezpečenstvo. Na druhej strane politické ambície Franskej ríše a jej spojenectvo s Bulharskou ríšou, ktorá susedila s Vel'kou Moravou, pravdepodobne viedli Rastislava k rozhodnutiu získat’ spojenectvo s Byzanciou a dosiahnut cirkevnú a politickú samostatnost'.

Niet pochýb o tom, že politická situácia v strednej Európe v 9. storočí bola vel’mi komplikovaná. Slovania na Velkej Morave sa ocitli uprostred záujmov Byzantskej a Franskej ríše a otázne

nam. To posli nam, vladyko, episkopa i učitelja takovaho. Ot vas bo na vsja strany vsehda dobryj zakon ischodit."

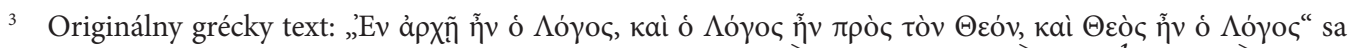

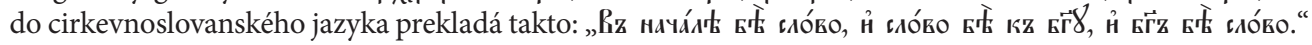

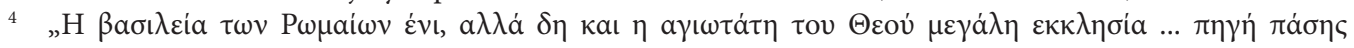

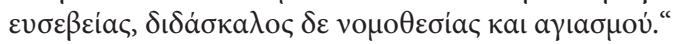


je, do akej miery vplyv Franskej ríše mohol vystriedat vplyv Východorímskej (Byzantskej) ríše. Pokrestančovanie pohanských etník v tomto období (Ivanič 2016, 123-130) síce začalo menit’ kultúrny a duchovný charakter obyvatelstva strednej Európy, ale súviselo to aj s presadzovaním politického, hospodárskeho i kultúrneho vplyvu, ktorý rozhodujúcim spôsobom formoval politickú a kultúrnu identitu tohto regiónu. V. Gluchman $(2017,69)$ vo svojej analýze stredoeurópskej politiky tohto obdobia a využívania, či lepšie povedané zneuživania krestanstva franskými panovníkmi vystihol podstatu mocensko-politického riešenia otázok na Vel'kej Morave.

Pri kritike franského vplyvu na území strednej Európy sa stretávame s názorom, že na dvore Karola Velkého vznikla idea jednotnej krestanskej ríše s cielom pokrestančit pohanov, ale v skutočnosti išlo o snahu šírit krestanskú vieru medzi pohanmi kvôli mocenským, politickým, hospodárskym a ideologickým záujmom Franskej ríše (Gluchman 2017, 64-65). To by však znamenalo, že franskí misionári zneužívali krestanstvo primárne na ideologické ovládanie podrobených krajín a nerešpektovali skutočné poslanie Cirkvi (Vlasto 1970, 26). Princípy šírenia krestanstva sú absolútne odlišné a tvrdenie, že krestanstvo podporuje vykoristovanie, sa prieči základným krestanským hodnotám. Z toho vyplýva, že dekadenciu ideologicky chápaného krestanstva, ktoré šírilo krestanskú vieru násilným spôsobom, nie je možné zovšeobecňovat. Na túto problematiku je nevyhnutné sa pozerat' komplexnejšie, ale hlavne bez predsudkov, ktoré je cítit vo viacerých ideologicky ladených publikáciách.

Napriek tomu, že cyrilo-metodská misia vyžiadaná kniežatom Rastislavom nedokázala trvalo začlenit’ Vel'kú Moravu do okruhu krajín patriacich do sféry byzantského mocenského vplyvu, zostavenie slovanskej abecedy, vytvorenie slovanského písomníctva a zavedenie slovanského jazyka do liturgie vytvorilo najúčinnejší prostriedok na presadzovanie byzantského vplyvu medzi slovanskými národmi. Používanie slovanského jazyka pri bohoslužbách znamenalo odstránenie latinčiny, ktorú na Velkej Morave presadilo nemecké duchovenstvo. Tento spor sa vyhrotil a po Metodovej smrti v roku 885 vyústil do vyhnania jeho žiakov z Vel'kej Moravy, ktorá sa tak definitívne dostala do rúk franskej moci. Následkom týchto udalostí bolo zničenie práce Konštantína Filozofa a Metoda v tomto regióne, ktorý sa dalej vyvíjal v duchovnej sfére latinského Západu. Kultúrny odkaz cyrilo-metodskej misie však prevzali južní a východní Slovania (Zástěrová 1996, 18), ktorí sa začlenili do krestanstva byzantskej tradície a stali sa členmi vel'kého kultúrneho spoločenstva,

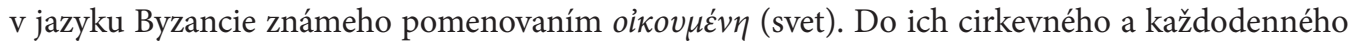
života sa v nezmenenej forme začali prenášat mnohé kultúrne prvky, ktoré formovali ich hodnotový systém. Postupne sa u nich začalo rozvíjat aj národné a náboženské sebavedomie.

Pri hodnotení franského či byzantského vplyvu na región strednej Európy musíme mat na zreteli, že "nevedomost’ a akákolvek ideologická zaujatost tak či onak sú najhoršími radcami v každom vedeckom výskume“ (Matsoúkas 1997, 114). Našim cielom preto nie je zaoberanie sa kontroverznými otázkami, ktoré sa týkajú dominantného vplyvu jednej či druhej imperiálnej mocnosti na politický a hospodársky rozvoj krajín strednej Európy, ale hladanie zdroja hodnôt v kultúrnom živote Slovanov, ktorí sa postupne formovali do štátnych útvarov v strednej, južnej a východnej Európe.

\section{Slovanské písmo ako kultúrna hodnota}

Jednou z obvyklých metód byzantskej diplomacie bola snaha o pokrestančenie a skultúrnenie národov v blízkosti byzantských hraníc a ich integrácia do sféry vplyvu Byzantskej ríše (Obolensky 1963, 45-61; Chrysos 1992, 25-39). Misia Konštantína Filozofa a Metoda na Velkej Morave v roku 863 bola príkladom byzantskej diplomacie, ktorá zachovaním úcty k jazyku a kultúre iných národov prispela k rozkvetu kultúry bez rasových, etnických a jazykových predsudkov (Matsoúkas 2010, 
432). Táto vyspelá byzantská kultúrna politika prostredníctvom cyrilo-metodskej misie umožnila Slovanom stat’ sa vyspelým národom a rozvíjat svoju vlastnú kultúru, jazyk a myslenie.

Byzantský cisár Michal III. ponúkol Rastislavovi a prostredníctvom neho celému slovanskému svetu nové písmo (abecedu) ako kultúrnu hodnotu. Slovania dovtedy nemali vlastné písmo, preto abeceda bola pre nich neocenitel’ným darom, ktorý ukrýval hlbšiu symboliku. Na jednej strane morfologicky nesúvisela so žiadnou známou abecedou vtedajšieho sveta - a samozrejme ovela menej s gréckou - ale na druhej strane jej pôvod bol čisto byzantský. Pre zostavenie hlaholskej abecedy Konštantín Filozof použil písmená a znaky z byzantských šifrovacích abecied a $\mathrm{z}$ astronomických, alchymistických a iných symbolov, ktoré sa v Byzancii použivali celé stáročia, a stretávame sa s nimi už od doby papyrusov. Pomocou týchto znakov bola vytvorená úplne nová, umelá a neobvyklá abeceda, ktorá mala symbolizovat aj nezávislost’ a samostatnost' slovanského sveta. Abeceda bola nástrojom na zapísanie jazyka Slovanov, ktorý umožňoval zachytenie osobitých hlások a zavedenie pravopisu. Konštantín Filozof a Metod spolu s abecedou odovzdali Slovanom aj texty posvätných kníh, preložených z gréckeho do slovanského jazyka, čím sa pre slovanský svet otvorila možnost̉ prenášania gréckych slov a významov, ktoré im dovtedy neboli známe. Slovanskému ludu bola tak ponúknutá vel’mi bohatá slovná zásoba gréckych abstraktných pojmov a zložených slov (Tachiaos 2006, 24-25). Nová slovná zásoba, ktorá sa začala zavádzat’ do života Slovanov, pochádzala $\mathrm{z}$ doslovného prekladu posvätných textov z gréckeho do slovanského jazyka. Tento preklad prenášal slovanským adresátom nielen bohatstvo významových systémov gréčtiny, ale aj štruktúru jazyka, nové vyjadrovacie prostriedky a syntax. Navyše, „prostredníctvom prekladov byzantských teologických prác, bohoslužobných textov a vyučovania na Velkomoravskej škole sa na naše územie dostali myšlienky byzantských filozofov a teológov, byzantská liturgická prax, bohoslužobné a patristické texty, vieroučné texty, ale aj byzantský občiansky (civilný) zákonník a Nómokánon" (Zozulaková 2016, 150).

$\mathrm{Na}$ začiatku christianizácie Slovania prijali základné texty, ktoré slúžili pre bohoslužobné

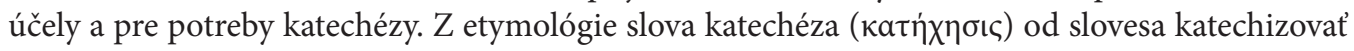

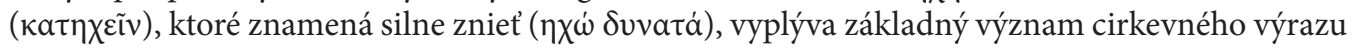
katechéza a vyjadruje, že Božie slovo znie v ušiach človeka, ktorému prináša odkaz spásy a volá ho,

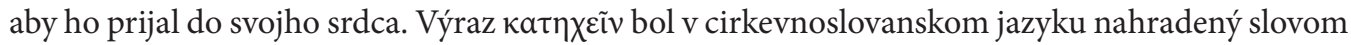
оглашати, с̌о znamená niekoho hlasite s niečím oboznamovat', na niečo upozorňovat', informovat'. Slovom katechéza sa vyjadruje „priame učenie, ktoré sa opieralo o počúvanie, oboznamovanie, svedectvo, živé slovo“" (Konkoúlis 2000, 37).

Významnú úlohu pri katechizácii zohrali grécki kňazi, ktorí boli zároveň prvými vodcami Slovanov v novej viere. Grécke duchovenstvo, ktoré prišlo do slovanských krajín učit novej viere, sprevádzali mnísi, ikonopisci, architekti, remeselníci, a dokonca aj obchodníci, ktorí Slovanom z Byzancie dovážali predmety umeleckého remesla používané pri bohoslužbách. Písomné pamiatky byzantského pôvodu boli doplnené aj o písomné alebo ústne poznámky a týkali sa spôsobu čítania textov, ich prednesu v chráme a pohybovania sa počas bohoslužobných obradov. Zároveň sa začali vytvárat nové pravidlá spoločenského správania, ktoré mali čisto byzantský pôvod.

\section{Hlaholské a cyrilské písmo}

Po zavedení krestanstva bulharská šlachta neprijala hlaholské písmo a trvala na zachovaní gréčtiny, ktorá bola prvým oficiálnym písaným jazykom prvého bulharského štátu. O používaní gréckeho jazyka Bulharmi pred ich pokrestančením svedčí množstvo epigrafov, ktoré tvoria dôležitý prameň bulharských, ale aj byzantských dejín (Tachiaos 2006, 43). Kedže Bulhari trvali na zachovaní posvätnej elegancie gréckej majuskuly, začiatkom 10. storočia bolo v Bulharsku hlaholské písmo 
nahradené cyrilským, ktoré vytvoril preslavský biskup Konštantín a venoval ho svojmu učitelovi Konštantínovi Cyrilovi (Dobrev 1995, 301-316). Cyrilské písmo, ktoré sa opieralo o byzantskú majuskulu, bolo vytvorené v dobe, ked’ sa v Byzancii toto písmo nahradilo minuskulou. Odvtedy cyrilské písmo prevládlo u všetkých Slovanov, ktorí prijali kultúru z Byzancie a zostali spojení s byzantskými hodnotami. Cyrilské písmo sa pre Slovanov stalo spojujúcim článkom a malo pre nich vel'ký význam (Tachiaos 1994, 43-49), pretože im umožnilo komunikáciu prostredníctvom spoločného jazyka, ktorý sa používal hlavne pri bohoslužbách.

V tom istom období v Bulharsku vzniklo krátke, ale hodnotné dielo O písomníctve, za autora ktorého býva považovaný istý tajomný mních Chrabr (Kuev 1967; Dzhambeluka-Kossova 1980). Niektorí odborníci na základe výskumu pod týmto menom, odvodeným od slova chrabrý - udatný, odhalili bulharského panovníka Symeóna, ktorý mal grécke vzdelanie. S touto hypotézou prvýkrát prišiel bulharský historik V. Zlatarski (1971, 820-829). Uvedené dielo prezentuje prevahu slovanského písma nad gréckym s odôvodnením, že grécke písmo je výtvorom mnohých osôb na základe fenického písma a prešlo rôznymi etapami spracovania, zatial' čo slovanské písmo vdaka Božiemu osvieteniu jednorázovo zostavil iba Cyril špeciálne pre Slovanov. Približne v tej istej dobe preslavský biskup Konštantín na základe byzantskej predlohy dvanást’slabičnej básne zostavil prvé slovanské básne, ktorých prvé kritické vydanie realizoval R. Nahtigal (1943, 41-156). V jednej z básní autor nazýva Slovanov „novým národom“, čo naznačuje, že Slovania, ktorí prijali krestanstvo, vstúpili do dejín ako novorodený národ s tolkými právami, s kolkými vstúpili predtým Gréci a Rimania. Ide o prvé, ešte velmi nejasné náznaky dialektiky vo vzţahu testátora a dediča, darcu a príjemcu daru, dialektiky, ktorá neskôr nadobudne konkrétnejšie črty (Tachiaos 2006, 30). Prostredníctvom týchto textov sa na Bulharmi ovládaných územiach začal proces absorbovania byzantských kultúrnych hodnôt.

\section{Slovanské písomníctvo ako kultúrna hodnota}

Okrem slovanského písma (abecedy) existovali aj dalšie procesy, ktoré dopĺňali kumulovanie byzantských prvkov v kultúrnom živote slovanských národov. Bolo to písomníctvo, ktoré sa pre Slovanov stalo základnou osou kultúrneho vývoja s charakteristickou recepciou byzantských kultúrnych a duchovných hodnôt (Zástěrová 1996, 18). Výskum v posledných desatročiach potvrdil, že Byzantská ríša výrazne ovplyvnila nielen slovanskú, ale aj európsku kultúru, avšak „proces prenikania a pôsobenia jednej kultúry na kultúru druhú je jav velmi zložitý, pokial ho nechápeme len ako určitý kontakt, dotyk, efemérne ovplyvnenie, ale vidíme v ňom jav dlhodobejšieho trvania a trvalejšieho zakomponovania určitých javov, prechádzajúcich z kultúry odovzdávajúcej do kultúry prijímajúcej" (Avenarius 1992, 11).

Prenášanie byzantských hodnôt do slovanského kultúrneho prostredia prostredníctvom preložených gréckych písomných pamiatok bolo silným kultúrnym faktorom, ktorý výrazne formoval slovanský svet a vytváral duchovnú identitu Slovanov. Proces prenášania byzantskej kultúry do slovanského prostredia, ktorý historik ruskej literatúry a kultúry D. S. Likhachov (1968, 30-33) nazval „vštepovanie“, A. Tachiaos $(2006,27)$ považuje za „absolútne vydarený“ a uvádza, že „Byzancia, ktorá bola zdrojom kultúry na najvyššej úrovni vo svete, vštepila (preniesla) do slovanského sveta nevyčerpatelné bohatstvo poznania, vzdelania a právnych noriem. To, čo Byzancia získala na historickej ceste počas celých stáročí, a to, čo zdedila od starých gréckych, rímskych a iných východných kultúr, bola vyzvaná odovzdat' Slovanom v časovo krátkom procese“ (Tachiaos 2006, 30).

Vštepované byzantské prvky sa postupne absorbovali do života a myslenia Slovanov. Vo vštepovaní však neexistuje prvok vplyvu, pretože vplyv predpokladá existenciu homogénnych systémov, prijímajúcich nové prvky, ktoré sa dostanú do ich štruktúr alebo ich nejakým spôsobom 
ovplyvňujú, zatial čo vštepovanie sa uskutočňuje na území ešte neúrodnom, nekultivovanom, a to, čo sa do neho vštepuje, aktivizuje skryté možnosti pre tvorivost’ a produktivitu. Hlavnými faktormi, prostredníctvom ktorých fungovalo byzantské vštepovanie a následne jeho vplyv na Slovanov, boli preložené grécke texty do slovanského jazyka. Išlo predovšetkým o biblické a liturgické texty. Po týchto prvých prekladoch sa do slovanského sveta začína zavádzanie širšieho okruhu textov so špecializovanejším obsahom. Dalo by sa očakávat', že Slovania sa prostredníctvom týchto textov mohli oboznámit’ s vtedajším duchovným a intelektuálnym životom Byzancie, že sa mohli oboznámit s filozofickými, teologickými a vedeckými diskusiami, ktoré zamestnávali byzantskú intelektuálnu verejnost', že mohli byt informovaní o tom, aké prúdy myslenia a uvažovania kolovali v hlavnom meste Byzantskej ríše, a všetko toto mohli preniest' do svojich krajín. Žial', nestalo sa tak.

V tejto súvislosti vel'mi kriticky vyznievajú slová gréckeho historika A. Tachiaosa $(2006,31-$ 32), ktorý tvrdí, že v Byzancii od 9. do 12. storočia prekvital duchovný život s významnými osobnostami a diskusiami o dôležitých teologických, filozofických a vedeckých otázkach, ako aj písanie významných diel týkajúcich sa týchto tém, avšak slovanský svet nič netušil, čo sa tam deje a zostal na okraji všetkých týchto procesov. Napriek kontaktom slovanského sveta s velkými byzantskými centrami, kde sa realizovalo prepisovanie rukopisov a vznikali významné diela, Slovania, ktorí prichádzali do významných centier Byzancie, ako boli Konštantínopol s velkými monastiermi (Studitský a Evergetidos), neskôr aj na Svätú Horu Atos, neprekladali diela súdobých byzantských myslitelov, ale sústredili sa na preklady textov autorov ranokrestanského obdobia.

Zodpovednost' za toto vylúčenie Slovanov z byzantského kultúrneho dedičstva je možné na jednej strane pripísat' gréckemu duchovenstvu, ktoré ich nad’alej viedlo, na druhej strane aj samotným Slovanom, ktorí vyberali a prekladali texty podla vlastného výberu, pretože si boli vedomí toho, že im chýbajú základné vedomosti, nevyhnutné pre pochopenie diel súdobých byzantských intelektuálov. V Byzancii sa celé stáročia rozvíjala kultúra a kontinuálne pokračovala antická grécka filozofia (Tatákis 1977, 22). Slovania sa však začali oboznamovat’ s krestanským učením, preto od nich nemôžeme očakávat', aby hned' po prijatí krestanstva boli schopní študovat’ antickú grécku filozofiu a pochopit myslenie Platóna, Aristotela či Plotína. Bolo prirodzené, že najprv sa museli oboznámit’ s textami ranokrestanských autorov a pochopit hlboké teologické významy myslenia Atanáza Alexandrijského, Vasilija Vel'kého, Gregora Teológa, Gregora Nysského či Maxima Vyznávača. Prostredníctvom textov týchto významných krestanských myslitelov, ktorí boli konfrontovaní s antickou gréckou filozofiou, sa do slovanského kultúrneho priestoru postupne prenášali teologické a filozofické interpretácie sveta, človeka i spoločnosti.

\section{Záver}

Napriek tomu, že vedecké poznatky v posledných rokoch značne pokročili, dodnes nebol zostavený kompletný zoznam byzantských textov preložených do starých slovanských jazykov. Faktom však ostáva, že Slovania sa nikdy dokonale neoboznámili so súdobým myslením v Byzancii. Velký pokrok nastal až v 14. storočí, ked’ do slovanského jazyka boli prvýkrát preložené tzv. Areopagitské spisy, ktoré sa pohybovali v novoplatónskych kategóriách myslenia a boli nevyhnutným predpokladom pre pochopenie velkých mystických byzantských autorov (Tachiaos 2006, 32). Slovania v tomto období, poznačenom isychastickými (hesychastickými) spormi, dostali vel'ký impulz k teoretickému uvažovaniu. Neskôr sa objavili ruskí intelektuáli, ktorí Konštantínovi Filozofovi a Metodovi spätne vyčítali zodpovednost’ za to, že medzi Slovanmi od začiatku nepresadili grécky jazyk, aby im umožnili priamo komunikovat’ s duchom antického Grécka (Florovskij 1937, 5-6). Tu sa však celkom prehliada skutočnost', že Slovania na to nemali vytvorený nevyhnutný základ. 


\section{REFERENCES}

Avenarius, Alexander. 1992. Byzantská kultúra v slovanskom prostredí v 6. až 12. storočí. K problému recepcie a transformácie. Bratislava.

Dobrev, Ivan. 1995. Кирилица [Cyrillic]. In Кирило-Методиевска енциклопедия [CyrilloMethodian Encyclopedia], T. 2. Sofia, 301-316.

Dzhambeluka-Kossova, Alda. 1980. Черноризец Храбър. О писменехь [Chernorizets Hrabar. About the letters]. Sofia.

Florovskij, Georgij. 1937. Пути русского богословия [The ways of Russian theology]. Paris.

Gluchman, Vasil. 2017. Krestanstvo a morálka v stredoeurópskej politike 9. storočia. [Christianity and Morality in Central European Politics of the 9th Century]. In Konštantínove listy [Constantine's Letters] 10/2, 62-74.

Havlik, Lubomír E. 1992. Kronika o Velké Moravě. Brno.

Chrysos, Evangelos. 1992. Byzantine Diplomacy, A. D. 300-800: Means and End. In Byzantine Diplomacy. Papers from the Twenty-fourth Spring Symposium of Byzantine Studies. Cambridge, March 1990, eds. Jonathan Shepard and Simon Frankling (Aldershot: Variorum), 25-39.

Ivanič, Peter. 2016. The Origins of Christianity in the Territory of Czech and Slovak Republics within the Contexts of Written Sources. In European Journal of Science and Theology 12/6, 123-130.

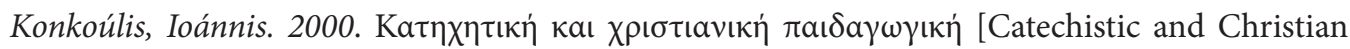
pedagogy]. Thessaloniki.

Kuev, Kuio. 1967. Черноризец Храбър [Chernorizets Hrabar]. Sofia.

Likhachov, Dmitriy Sergeyevich. 1968. Древнеславянские литературы как система. Славянские литературы: VI Международный съезд славистов [Old Slavic literature as a system. Slavic literatures: VI International Congress of Slavists] (Прага, авг. 1968). Moscow, 5-48.

Marečková, Dagmar. 1969. Moravské poselství do Cařihradu jako řecky dokument. In Slovo, 1819, 109-139.

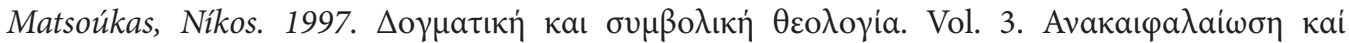

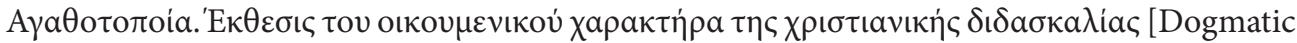
and symbolic theology. Vol. 3. Remediation and Good Condition. Exposing the universal character of Christian teaching]. Thessaloniki.

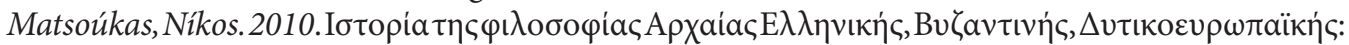

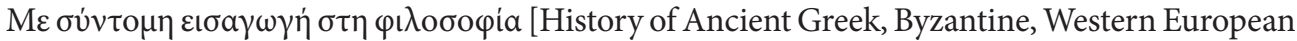
philosophy: A brief introduction to philosophy]. Thessaloniki.

Miklosich, Franz - Müller, Joseph. 1862. Acta Patriarchatus Constantinopolitani, I. Vindobonnae.

Nahtigal, Rajko. 1943. Rekonstrukcija treh starocerkvenoslovanski izvirnih pesnitev. In Razprave Akademije znanosti in umetnosti v Ljubljani. Filozofsko-filološki-historični razred 1, $41-156$.

Obolensky, Dimitri. 1963. The Principles and Methods of Byzantine Diplomacy. In Actes du XII Congrès International des Études Byzantines, I. Belgrade, 45-61.

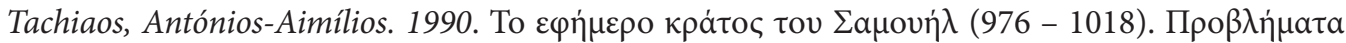

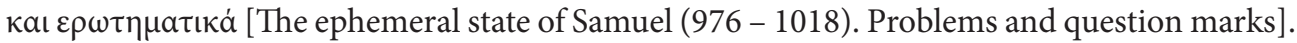
Thessaloniki.

Tachiaos, Anton-Émil. 1994. Вечното значение на кирилицата [Eternal meaning of the Cyrillic alphabet]. In Годишник на Софийския университет „Св. Климент Охридски“ [Yearbook of the University „St. Kliment Ohridski“ in Sofia] 87 (6), 43-49. 


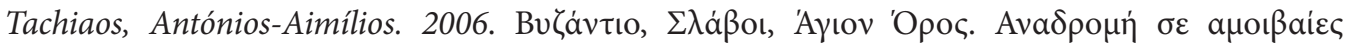

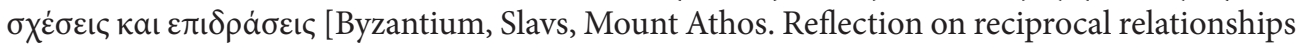
and influences]. Thessaloniki.

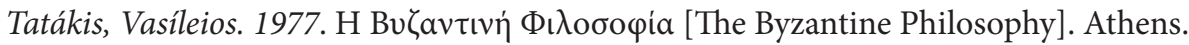

Vašica, Josef. 1966. Literární památky epochy velkomoravské 863 - 885. Praha.

Vavř́nek, Vladimír. 2001. Velká Morava mezi Byzancí a latinským Západem. Velká Morava mezi Východem a Západem, Sborník příspěvků z mezinárodní vědecké konference, Uherské Hradiště, Staré Město 28.9. - 1.10.1999. Brno, 413-419.

Vlasto, Alexis. 1970. The Entry of the Slavs in the Christendom. Cambridge.

Zástěrová, Bohumila. a kol. 1996. Dějiny Byzance. Praha.

Zlatarski, Vasil. 1971. История на Българската Държава през средните векове [History of the Bulgarian State during the Middle Ages]. Tom I. Sofia.

Zozulaková, Viera. 2016. Praktická filozofia v živote Konštantína a Metoda [Practical Philosophy in the Lives of Constantine and Methodius]. In Konštantínove listy [Constantine’s Letters] 9/1, 149-157.

\begin{abstract}
SUMMARY: A SOURCE OF VALUES IN THE CULTURALLIFE OF THE SLAVS. Slavic script and Slavonic literature belong to the most important cultural values brought by ConstantineCyril and Methodius to Great Moravia. The source of these values was the Eastern Roman (Byzantine) Empire and its culture which significantly influenced the history of Slavic nations and their position within the European cultural space. Three historical documents discussed in the paper clearly demonstrate the supremacy of the Byzantine Empire as a cultural centre and they represent solid evidence for diachronic recognition of the dominant value of Byzantine as a source of spiritual wealth, values and legal norms from the Slavs' perspective. The first text is the sixth chapter of The Life of Constantine-Cyril which contains Constantine's dialogue with the Arabs in 851. The second text is an epistle sent from the Great Moravian Prince Rastislav to the Byzantine Emperor Michael III in 862 and the third text is an epistle of the Prince of Moscow Simeon addressed to the Byzantine Emperor John Kantakouzenos in 1347. The paper argues that these texts define the starting point from which the study of reception of Byzantine cultural and spiritual values in Slavic countries can be initiated. Although the Cyrillo-Methodian mission requested by Prince Rastislav failed to include Great Moravia permanently into the network of countries belonging to the Byzantine sphere of influence, the creation of the Slavic alphabet, the origins of Slavonic literature and the use of a Slavic language in liturgy were the most efficient means to promote Byzantine influence on Slavic nations. Cultural legacy of the Cyrillo-Methodian mission moved to the South and Eastern Slavs who accepted Christianity of the Byzantine tradition and became the members of a large cultural community called in the Byzantine

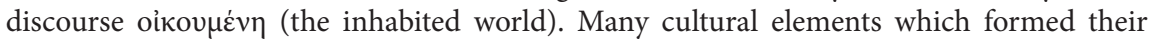
value system became part of their religious and everyday life.
\end{abstract}

prof. ThDr. Ján Zozulak, PhD.

Constantine the Philosopher University in Nitra

Faculty of Arts

Department of Philosophy

Hodžova 1

94974 Nitra

Slovakia

jzozulak@ukf.sk 